\title{
Understanding the Emergence and Evolution of New Business Models in the UK Regenerative Medicine Sector
}

Authors: Banda Geoffrey¹; Tait Joyce²; Andrew Watkins²; Omid Omdivar ${ }^{3}$; Mittra James² 1 and 2. The Innogen Institute

The University of Edinburgh

Old Surgeons Hall

High School Yards

Edinburgh

EH1 1LZ

Corresponding author ${ }^{1}$ : Geoffrey.Banda@ed.ac.uk

3. Aston University

Aston Business School

Birmingham

B4 7ET

\section{Abstract}

This paper identifies, characterises and analyses six evolving regenerative business (RM) models in the UK based on 10 cases we studied. Our conceptual framework extracts four key elements from contemporary business model and value chain literature; architecture/structure, value creation and extraction, networks and linkages, and governance. Using the case study method, we identified the following business models: materials and service provision; early exit: Phase I/II; manufacturing and scale up; translational services; virtual; and integrated. All the business models are still pre-revenue, except for manufacturing and scale up which generates revenue from contract manufacturing therapies for clinical trials. The RM sector is still evolving and consequently the business models are still in flux. Two key challenges for the sector are scalability and sustainability, which creates challenges for pre-emptive policy and practice interventions. We conclude that pre-emptive policy design should support value chain upgrading, paying particular attention to short, medium and long-term sustainability of the RM innovation eco-system, especially evolution of a broad base of SMEs that can take over when public funding is withdrawn. A proportionate and adaptive regulatory environment will be critical to supporting evolving business models even as value chain upgrading occurs.

\section{Introduction}

Regenerative Medicine (RM) is recognised as one of the UK's Eight Great Technologies (Department for Business, Innovation and Skills (BIS), 2013), with claims to solve currently intractable health needs, create new industries and contribute to the bioeconomy. Its significance stems from its "claim to cure" by restoring normal cell, organ and tissue form and 
function (Wang, 2013), bringing benefits to patients and health service providers. RM therapies could be one-off, providing a cure for a disease, or repeated at regular intervals for chronic conditions like diabetes. Therapy may be: (i) autologous, where a patient's cells are harvested, manipulated in a laboratory, factory or clinical setting and reintroduced into the same patient, or (ii) allogeneic, where a patient receives cells manufactured in a central facility from a single donor, serving large numbers of patients over a large geographical area (Couto et al, 2012; Omidvar et al., 2014). Key determinants of therapy choice and hence business models are disease area, and availability of cell culture starting materials, which drive strategic choices for production, process control, logistics, and regulatory framework applied (Franklin and Kaftantzi, 2008).

The Cell and Gene Therapy Catapult (CGTC) reports a 60\% increase in the licenced good manufacturing practice (GMP) accredited production space $\left(8000 \mathrm{~m}^{2}\right.$ by 2019$)$, and $30 \%$ increase in employment, making the UK the most advanced RM region in Europe ${ }^{1}$. The CGTC CEO reported in an interview with Ben Hargreaves that the industry grew from a few firms to over 70 by 2018 and raising of $£ 2.5$ billion². However, the UK and European RM terrain has been dominated by small to medium enterprises (SME) and academic research institutions (BIS, 2011). Pathways to market are uncertain and regulation is not always proportionate and adaptive to RM needs (Tait and Banda, 2016), constraining resource-poor SMEs from developing radical innovations. The UK House of Lords Science and Technology Committee Regenerative Medicine Report (HoL S\&TC, 2013) and Omidvar et al., (2014) identified the following barriers to translation of the UK's scientific strength in RM 'from bench to bedside': regulation, intellectual property (IP) protection, clinical trials design, manufacturing capacity, National Health Service (NHS) procurement strategies, National Institute for Health and Care Excellence (NICE) evaluation processes, and lack of innovative funding models for commercialisation. The UK regulators have reported adopted the fellow traveller concept, where they continuously learn from innovators and adapt regulatory requirements to the idiosyncrasy of the RM sector (Banda et al, 2018). Thus, RM integration into healthcare value chains requires better conceptualisation of the complexities of its business models. We use the business model concept as a heuristic device and sense-making tool that can help in designing context-specific policy, regulatory and investment intervention packages that can facilitate better commercial development and risk management. Although ordinarily used for well-established sectors/businesses, we apply the business model concept to RM, an emerging life sciences radical innovation, where innovators face a dual challenge of inventing new business models and value chains with no precedence, whilst concurrently developing radical innovations (Tait \& Wield in this issue).

We consider the value and capacity of conventional business model approaches to deal with the RM complexities. Our study uses ten case studies based on research carried out between 2015 and 2017 that built on previous work by Mittra et al (2014) and Omidvar et al (2014). The overall objective of this paper is to identify, characterise and analyse a typology of emerging UK RM business models in recent years. Using a conceptual framework developed from business model and value chain theory, we investigate the architecture/structure, value

\footnotetext{
${ }^{1}$ https://ct.catapult.org.uk/news-media/manufacturing-news/research-highlights-uk-growing-manufacturingindustry accessed 6 July 2019

2 https://www.biopharma-reporter.com/Article/2018/11/26/UK-cell-and-gene-therapy-ecosystem-second-tonone accessed 6 July 2019
} 
creation and extraction, networks and linkages, and governance structures that characterise evolving RM business models. Our contribution to literature is two-fold. First, we apply exante the business model concept to RM, an emerging radical innovation with gaps in its value chains, that needs to negotiate complex ecosystem influences, including regulatory systems and standards, financial support systems, and new market dynamics (Banda et al, forthcoming) and with no clear route to market. Second, we identify six business models that describe the logic of the firms in the sector, and at a macro-level we show the architecture of the UK RM sector through the inter-linkages of the six business models.

The paper is structured as follows. In section 2 we discuss the methods used, and in section 3 we review and analyse the literature on the business model concept and the challenges of applying it ex ante to regenerative medicine. In section 4 we present and discuss the six UK RM business models we identified, and conclude with section 5 .

\section{Methods}

This study examined the dynamics of innovation within RM and the broader institutional readiness of the UK health system to adopt RM using the case study approach (Yin, 2003), focusing on the six RM business models identified (Table 1). The study ran for over two and a half years (2015-17) and we approached 20 firms/organisations of which 10 agreed to participate; we refer to these as cases. Access for interviews was difficult because of sensitivities on proprietary knowledge and competitive advantages. The 10 UK RM cases' activities ranged from immunotherapies to tissue regeneration. We held two rounds of semistructured interviews with the 10 cases. The first round of interviews with all 10 cases lasted from one to two and half hours depending on available time; the second round, to check the validity of our interpretation of the identified business models and company activities, was done telephonically with interviewees from eight out of the ten cases. All interviews except for one case were audio recorded after seeking informed consent from the interviewees. Notes were taken for the case that was not audio-recorded. The audio recordings were transcribed verbatim and coded manually to identify key themes we used to characterise and analyse the six business models and factors driving the strategic choices for the cases.

During the interviews, we sought to understand the interviewees' perception of their business model(s), what drove it, their organisational structure, and their unique product value proposition. We also sought to understand who manufactured the RM therapies and how they were manufactured, how the company navigated the regulatory framework, how they sourced funding and any networks and linkages that were important for them. We designed this to understand the nature of RM value chains, key linkages and what influenced collaborations. Names of respondents and cases have been anonymised as promised during the interviews.

Table 1. Type of organisations, therapy areas and stages, and funding sources of the 10 case studies.
Type of Organisation and Therapy Area
Funding Sources
Therapy Stage
Firm A: autologous - Immunotherapy
Grants + Private Equity. Clinical Trials $£ 70$ million 
Firm B: autologous - Immunotherapy

Firm C: autologous - Cell therapy and Surgery

Firm D: autologous - Tissue engineering and Surgery
Public + Private Equity + Clinical Trials Financial Institutions.

$£ 5$ million

Grants and Private Clinical Trials

Equity

Grants and Private

Equity. $£ 8$ million

anticipating Euro 7

million.

Grants

Grant + Others

Private Equity and

Grants. £40 million

Public

Public Organisation: allogeneic - Cells and organs

Firm G: allogeneic - Cell therapy

Research Consortium: allogeneic - Cell therapy

Private Equity + Public funds ( $£ 52$ million). Burn rate $£ 1 \mathrm{~m}$ per month

Grants: $~ £ 15$ million over 8 years
Animal Studies

CMO*

Clinical Trials

CMO*

Clinical Trials /

Compassionate Use

Clinical Trials - Specials / Unlicensed

Pre-Clinical

* Contract Manufacturing Organisation

\section{The business model concept and its application to regenerative medicine}

We built on the business model and value chain literature to construct the conceptual framework we use to identify, characterise and analyse the six RM business models in the ten cases we studied. There is generally lack of consensus on the business model concept's theoretical underpinnings, which attracts criticism because of interpretation and application fluidity across diverse disciplines (Al-Debei and Avison, 2010; Chesbrough and Rosenbloom, 2002). However, there is general acceptance of its utility as a framework for understanding the logic of an enterprise. It helps to explain how a business with an attractive value proposition, creates and extracts value by selecting a route to market that results in sustainable revenue inflows and profitability (Al-Debei and Avison, 2010; Osterwalder et al, 2005; Santos et al, 2009). The concept has mostly been applied ex-post, that is after resolution of technology, value chain, regulation and market development challenges. It is more complex to apply the concept ex-ante to RM, an evolving radically innovative sector with value chain gaps, problematic regulatory precedents (Tait and Banda, 2016), few products on the market and limited revenue inflows to make the business attractive to early stage funders. Cognisant of these complexities, and building on business model literature, we identified four elements we discuss below to construct a conceptual framework that we apply ex ante to RM business model. None of the current business model frameworks is able to explain in a robust manner the logic of this pre-revenue sector, as value creation and capture has not yet been realised extensively. 


\section{Architecture/Structure}

Osterwalder et al (2005) and Trimmers (1998) use the term architecture in their definition of business models, and Amit and Zott (2001) use structure to articulate how firms create and deliver value (Teece, 2010). Architecture and structure relate to form and function in biology or engineering for example, and represent a stable frame upon which related elements can be attached, organised or made sense of. Osterwalder et al's (2005) business model canvas uses this approach to distinguish activities relating to cost structures (key partners, key activities and value proposition that straddle revenue streams) and the revenue streams themselves (customer relationships and segments, and channels). Thus, the business model canvas provides a logical 'structure or frame' for organising cost and revenue drivers for a firm. Strategies deployed by management in executing these activities determine how good a firm is at creating and extracting value compared to its competitors. Trimmers (1998:4) uses a similar approach to define business models for electronic markets as "An architecture for the product, service and information flows, including a description of the various business actors and their roles, a description of the potential benefits for the various business actors, and a description of the sources of revenues".

Osterwalder et al's (2005) business models canvas cannot be applied to RM because although it captures RM cost structure/architecture of the business, it faces challenges because there are no revenue streams as products have not yet reached the market. All other business model definitions face this challenge when applied to pre-revenue enterprises, especially those with no regulatory or reimbursement precedence. Thus in our conceptual framework, we adopt the architecture/structure element to, in the broadest sense, describe how RM enterprises are organised and how they may create and extract value in the future through potential revenue.

\section{Value creation and extraction}

How to create, capture and deliver value is a common element across all business model definitions (Al-Debei and Avison, 2010; Teece, 2010) and we consider value one of the core elements of our conceptual framework. The notion of "economic value" as profits or return on investment is predominant, hence the allusion to value creation, value capture and value chains. Linder and Cantrell's (2000) focus on the value proposition and Osterwalder et al's (2005) treatment of the value proposition and value configuration highlight the importance of economic value to business models. Other authors use: value proposition and strategic objectives (Weill and Vitale, 2002); value model (Petrovic et al, 2001); value offering (Gordjin, 2002); customer value (Afuah and Tucci, 2003); and value architecture. Whilst it is easy to demonstrate economic value for established industries, for RM the task is difficult because products are still in early development or clinical trials, and supported largely by public research funding. Without reimbursement from approved products, economic value remains speculative even without considering the wider societal values (Mittra, 2016) generated by reducing recovery times, freeing up hospital space, enabling people to work, and reducing pressures on carers. Thus for RM, demonstrating economic value creation and extraction especially to investors is a major challenge, one that is faced by most disruptive innovation 
technology developers with speculative (?) business models with gestation periods of 10-15 years or more. Value, the second element of our conceptual framework, has significant funding and strategy implications for how healthcare systems will negotiate expensive future payments for therapies with claims to cure.

\section{Networks and Linkages}

We also build on Amit and Zott (2001), who incorporated Porter's (1985) value chain concept, including innovation and the economics of transaction costs into their analysis. Santos et al (2009) however criticised Amit and Zott (2001) and Zott and Amit (2008) for omitting the pivotal role played by relationships in intra and inter-firm linkages and constraints within and outside an organisation's system (Figure 1). Inter-firm linkages are critical for resource constrained RM SMEs, which cannot engage in all technological and regulatory learning necessary to bring a product to market, and therefore depend on external firms/organisations to procure products and services. Consequently RM business models will value external linkages which are critical for information flows (Trimmers, 1998), technology flows, and networks of partners and relational capital (Osterwalder et al, 2005), in addition to special roles and relationships amongst customers, partners and suppliers (Trimmer, 1998; Weill and Vitale, 2002). These activities require negotiating new networks and linkages, and value chain integration, which could lead to new organisational structures (Perkmann and Spicer, 2010), as various actors provide information, money, products and services flows (Figure 1).

Building on the value of networks and linkages, we are interested in the five-way relationships between RM-Innovators, their suppliers, other RM-innovators, regulators, patient/clinical settings, and investors' linkage dynamics. As figure 1 illustrates, the link between RM innovators and patients/clinical settings is the claim to cure with important linkages required for therapy adoption in order to maximise therapy utility. The link between RM-innovators and regulators is assurance of therapy safety and efficacy, which relate to macro-level governance issues embodied in cGMP (current Good Manufacturing Practice) and other regulations. Business viability and sustainability, economic value creation and extraction, as well as return on investment are the focus of the linkages between investors and RM innovators. RM-innovator to RM-innovator linkage covers competition, collaboration and value chain integration with the consequent micro-level value chain governance issues discussed under governance. The linkage between suppliers and RM-innovators is important for knowledge and product flows. As they interact, suppliers and innovators exchange inputs and there are opportunities for technological learning as RM innovators are integrated into their suppliers' value chains. In the next section, we focus on regulation and value chain governance.

Figure 1: Linkages among RM innovators, investors, regulators, and the patient/clinical settings and the factors at play when they interact. 


\section{Suppliers}

- Start-up Materials

- Technological Skills

- Therapy Development Skills

- Value Chain Integration

- Micro-governance Issues

\section{RM Innovator}

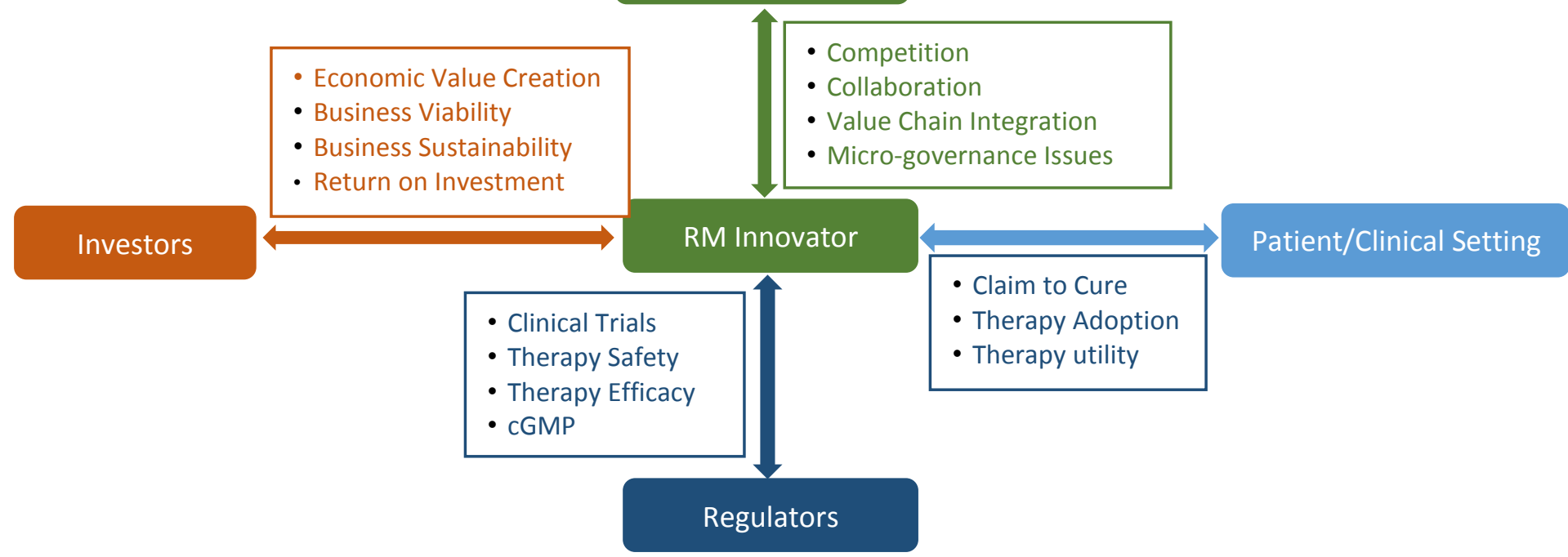

\section{Governance}

In our conceptual framework, the three elements of architecture/structure, value chain creation and capture, and networks and linkages are brought together by RM business governance at macro and micro levels including regulation of therapies and value chain governance respectively (Figure 1). Definitions of business models are applied mostly to sectors with light-touch regulation, omitting regulatory influence on manufacturing and quality assurance costs, and hence therapy profitability and firm viability. Tait and Banda (2016) and Tait, Banda and Watkins (2017) argue that proportionate and adaptive governance of innovative technologies is important in the early stages to allow many innovations to flourish to develop innovations with greatest value. These regulatory intricacies and complexities open up opportunities for early start RM businesses to engage in consultancy for latecomers.

In our conceptual framework, for firm-level governance, we adopt Gereffi et al's (2005) five value chain governance structures: markets; modular value chains; relational value chains; captive value chains; and hierarchy value chains. Gereffi et al $(2005 ; 86)$ describe market governance as the situation where information exchanged is not complex and transactions are easily governable, whereas modular value chains arise when the nature of the product is 
modular and specifications are codified which allows standards to reduce transaction costs and variation. Relational value chains on the other hand arise when product specifications are not codified leading to a greater reliance on tacit knowledge and mutual dependence. This is likely to be the situation with RM as the knowledge is a mix of codified and tacit knowledge. The third form is the captive value chain, which arises when products can be codified but are complex and supplier competence is low. In this case, value chain governance causes the lead firm to lock out others from receiving benefits of their first mover investment in development efforts. However, the challenge for RM is that SMEs do not have huge financial resources to exert lead firm influence on their suppliers. The fifth type of value chain governance is hierarchy when a triage of factors coincide; products are complex, their specifications cannot be codified, and there are no capable suppliers. This forces lead firms to develop in-house these capabilities, allowing the firm to easily exchange tacit knowledge and better manage intellectual property. This is not yet feasible for RM SMEs, as they do not possess the resources to develop all capabilities in-house. Prevalent value chain governance in RM is therefore likely to be relational (Figure 2).

\section{Findings and Discussion}

We identified six RM business models used by the 10 cases we studied, all pre-revenue firms except for CMOs (Table 1). In Figure 2, we have, for convenience and simplicity depicted a linear development of RM technologies from pre-clinical to clinical adoption, although we recognise that innovation is more complex, messy and iterative than this. The ten cases we studied encompassed a broad range of activities spanning pre-clinical work, translation and early manufacturing and clinical trials. Four cases were developing autologous therapies; four cases were developing allogeneic therapies, and one was involved in conducting animal studies for bone healing. The tenth case was a CMO developing cells and tissue to be used to generate data for drug discovery. None of the ten cases had obtained market authorisations in the UK or elsewhere. Two cases were CMOs and therapy developers assisting other firms involved in Phase 1 clinical trials. Table 1 shows that funding for the cases came from public sources in the form of grants and equity from philanthropic funders/business angels as well as UK and regional governments. The majority of activities were in rare disease indications, which present clinical trial recruitment challenges (Banda et al, forthcoming). We analysed RM business models using our conceptual framework, composed of four elements; architecture/structure, value creation and extraction, networks and linkages, and governance.

Figure 2. The Six RM business models identified in the 10 cases studied 


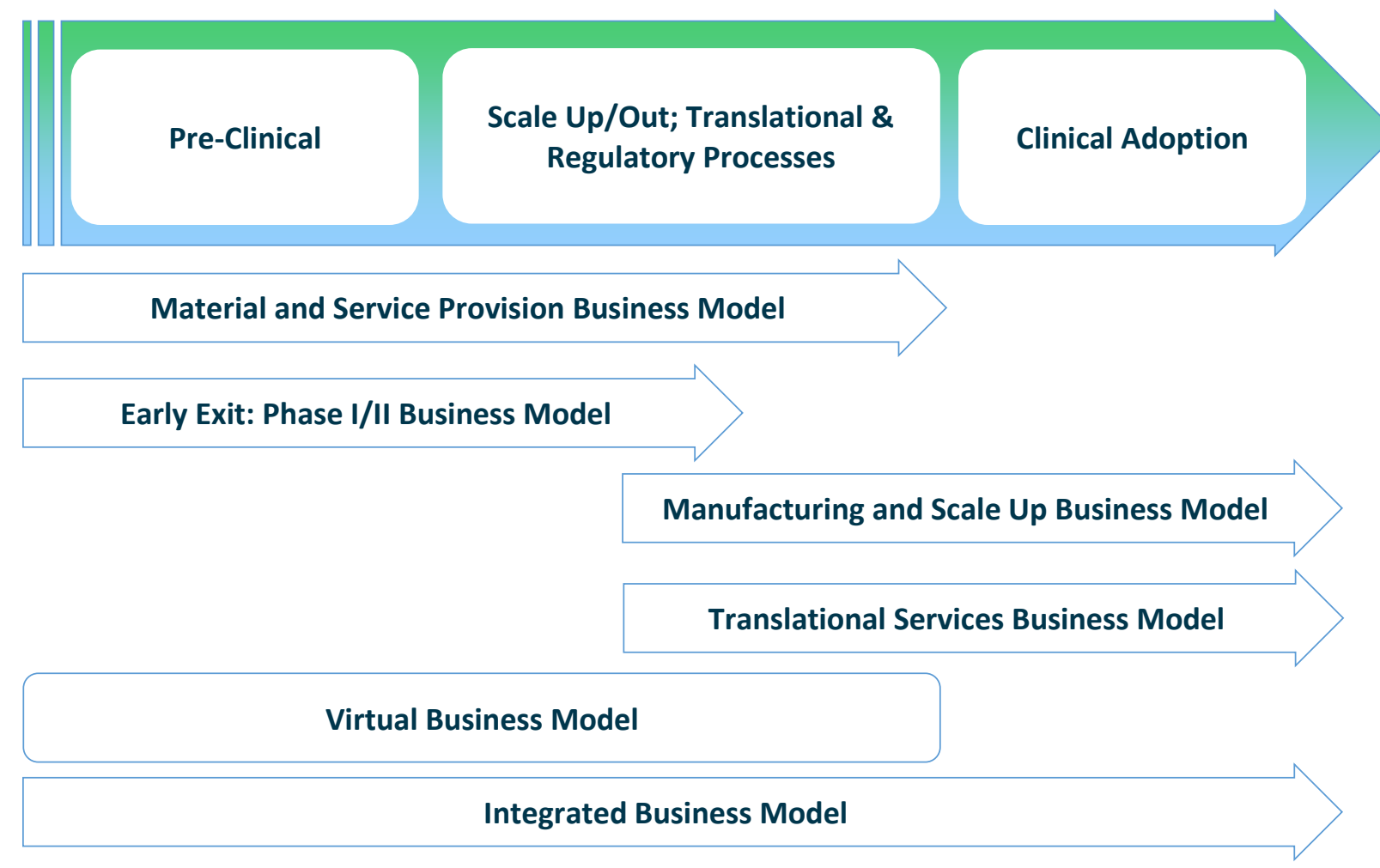

\subsection{Materials and Service Provision Model}

Our analysis of the 10 cases showed that although none had a product on the market, they have suppliers of inputs, equipment and knowledge for therapy development and clinical trials. These activities illustrate the Materials and Service Provision Business Model (Figure 2), composed of firms or organisations which through linkages with RM innovators supply biomaterials, cell culture and reagents, machinery and equipment, quality assurance and analytical services. Value is created and extracted from development and clinical trial activities and these actors have broad product portfolios spanning other life science experimental sectors.

We identified three representative categories; first, traditional suppliers of cell culture starter material, reagents and culture media; second, suppliers of RM therapy production machinery and equipment, and, third, RM innovators intending to use RM techniques to supply cells and tissue for pharmaceutical drug discovery and toxicology R\&D processes (Figure 2).

The media and reagents suppliers' small-volume, high-value product business model explains the huge cost driver of these inputs for RM as reported by all ten cases. RM organisations thought more competition could lower this aspect of manufacturing costs, or alternatively, reflecting the hierarchy value chain governance, they could bring in-house culture media and reagent manufacturing capabilities. However, due to resource limitations they still rely on traditional suppliers - demonstrating relational value chain governance.

Suppliers of manufacturing and imaging equipment are key linkages and knowledge exchange actors with RM innovators. Emphasising the importance of networks and linkages, specialist RM therapy equipment development, as one case we studied showed, requires co-designing with machine developers and fabricators an activity that engenders bi-directional learning 
between therapy developers and equipment manufacturers. This company was not interested in capturing IP on the developed machinery and equipment because they claimed that their competitive advantage was in delivering innovative immunotherapies.

In the third category, recognising that RM therapies are a long way from reimbursement, one company was both a $\mathrm{CMO}$ and therapy developer and was targeting early revenue generation by using RM techniques to generate data for pharmaceutical firms for drug modelling, toxicology and stratified medicine. The respondent from that case reported that:

"... one of the things which I'm very keen to do is ... build up the value chain so that we can ... take stem cells, ... make them into a particular lineage, ...do the assay, ... [toxicology] test and ... get data. ... we can therefore investigate new drugs and screen against large libraries which is traditional drug discovery. .... But you can do ...other things, which relate to stratified medicine, and this is where I particularly want to go..." (CEO, CMO and therapy development organisation, 2015).

The respondent reported that linking RM to stratified medicine accelerates development of biomarkers for targeting drugs to specific patient cohorts, which can lead to better clinical trial design for new drugs, drastically reducing the cost of clinical trials and leading to better clinical outcomes for responders. By integrating early RM activities into traditional pharma value chains, this organisation hopes to create and capture value at the early stages of the value chain and then re-invest the proceeds into future RM therapy developments. This project was still at the planning stage, but it highlighted the importance of networks and linkages in understanding the evolving business models and value chains.

\subsection{Early exit phase I/II business model}

The Early Exit Phase I/II Business model includes firms or organisations focusing on early stage RM therapy development and exiting the RM value chain by selling off IP or de-risked products. Their strategic intent is value creation through de-risking early stages of RM therapy development, demonstrating proof of concept, safety and efficacy (clinical trial phases I/II) and taking IP rights over innovative products and processes. Value appropriation arises through linkages with big pharma or biotechnology organisations. This model occurred in two university spin-off cases and a small cell therapy-manufacturing firm as reflected in this quote:

"The original idea with [firm $x$ ] at the start was the classic idea of develop something to a certain point and then sell it to big pharma" (CEO, Cell Therapy Manufacturing Firm, 2015).

A company with a broad product portfolio, also developing platform technologies, was interested in this approach as they intended to use IP sell-offs and out-licenced platform technologies to generate revenues which could be re-invested in the firm. Our study showed that a key driver of this business model was financial resource constraints - inability to raise patient capital, and general acknowledgement that RM products will not generate revenue in the short to medium term. In as much as there is a strategic focus to monetise IP, Pisano (2006) cautions that although there was IP monetisation in the biotech industry since the 1970s, it takes a long time for investors to get returns on investment. A key challenge for the sector is that the RM product is very close to nature and presents patentability challenges, whereas other IP assets such as trademarks, copyright and utility models can deliver cashflow 
generating assets. It is important to note that there are academics who are only interested in developing therapies but not entrepreneurship.

Our study indicated significant challenges to integrating RM and pharmaceutical business models. In Biotech, Li (2007) critiqued Pisano (2006) for neglecting the interplay between traditional pharma and biotech industries as a key source of financial flows for the survival of the biotech industry. However, for RM, both the business models and type of therapy are disruptive for traditional pharma. Better-formulated strategies that take account of long product gestation periods and value creation dynamics, nature of linkages and the idiosyncrasies of RM and pharma are necessary as illustrated in this remark:

"We behaved like a medical device company and tried to license the product [skin cell therapy] to medical device companies .... their product cycle was really short and they couldn't understand ... why this was going to take so long [and] ... involve large clinical trials ... when they [were] used to making medical device products, and shipping ... within months or early years. .... Then we suddenly decided, you know, we are more like a pharmaceutical [firm] in terms of our development cycle" (CEO, Cell Therapy Manufacturing Firm, 2015).

The dilemma faced by the quoted entrepreneur highlights the complexity of aligning the four elements (architecture/structure; value creation and capture; linkages and networks; and governance) of new business models with established business models. A common thread that emerged during the study was that RM value chains are difficult to integrate into contemporary pharmaceutical value chains. In their analysis of stratified medicine, Mittra and Tait (2012) observed that where new technologies offered both opportunities and challenges to conventional pharmaceutical $R \& D$, there was need to manage complex regulatory systems, sales, logistics and re-imbursement and to negotiate inter-sectoral collaborations with companies operating different business models. Although Academic Drug Discovery Centres/Consortia may be worth considering here, their utility for the RM sector is currently limited because, first RM has a niche focus, and second, our research indicates that being a pioneer has strategic and competitive advantage and therefore collaborations are difficult for emerging fields.

\subsection{Manufacturing and Scale Up Business Model}

The Manufacturing and Scale Up Business Model comprises firms or organisations which create and extract value by investing in cGMP compliant RM facilities and contract manufacturing therapies. They specialise in therapy production optimisation for clinical trials only. This business model can also be adopted by firms or organisations with in-house production needs, using excess production capacity for contract manufacturing as a strategic choice. The manufacturing and scale up business model is central to the other five RM business models (see Figure 1), because it is a critical linkage in the RM value chain that connects upstream therapy development actors with downstream translational activities in clinical trial design and management as well as clinical adoption.

Our study indicated that the UK did not have capacity to produce therapies at scale for clinical use. As at 2014, the Cell and Gene Therapy Catapult (CGTC) reported that the UK had 13 
cGMP (current Good Manufacturing Practice) RM facilities with 52 clean rooms (CGTC, 2014). An analysis of these CGMP RM facilities showed that they fall into four categories; academic, public sector, private sector and charities. Eight of the thirteen-cGMP RM facilities are in either the academic or public sector. Other publicly (and research grant) funded institutions used by the rest of the cases we studied in early translational stages included Guy's \& St Thomas' Hospital, NHSBT - Speke; Scottish Centre for Regenerative Medicine (Roslin Cells and SNBTS) and Great Ormond Street Hospital Cellular Therapy Laboratories. The other players with RM cGMP facilities included academic facilities at Kings College London, Imperial College, and University College London (UCL); and charities such as Cancer Research UK (CGTC, 2014). This underscores the observation that SMEs cannot afford to invest early in cGMP facilities, as reported by an autologous immunotherapy case:

[The CGTC]... de-risks the manufacturing... [and they]... do not have to invest in building [their] ... own [cGMP] building ... So [they] push the risk, [of] invest [ing] ...in a building, further down the development pathway.

Another RM case with a broad product portfolio, which had contracted out their cell manufacturing to an entity that shut down, indicated that they would use the CGTC Stevenage facility, demonstrating that government's investment in innovation infrastructure (Banda et al, forthcoming) is welcomed by the sector. However, if not carefully considered such interventions can in the short-term crowd out Small to Medium Enterprises (SMEs) from the innovation ecosystem, creating challenges when funding is later withdrawn (Banda et al forthcoming). Innovation anchor institutions such as the Scottish National Blood Transfusion Services (SNBTS), National Health Services (NHS) or National Health Systems Blood and Transplant (NHSBT) will be an integral part of RM value chains because of their critical role in providing source materials, production of therapies and their linkages with SMEs for therapy development and clinical delivery.

Contract manufacturing is the only RM activity generating revenue in the sector. Although the manufacturing and scale-up business model as understood from pharmaceutical or biotechnology perspectives as a mature one, for RM it is still immature and developing and, because of scarcity of skills and facilities, costs are still very high. A respondent from a CMO company reported that a contract manufacturer charges from $£ 10000-20000$ per week for a clean room. Equally onerous for RM SMEs is the fact that manufacturing optimisation learning costs are borne by them and not the $\mathrm{CMO}$. This is expensive given that it can take up to eight weeks to optimise a manufacturing protocol.

\subsection{Translational Services Business Model}

The Translational Services Business Model includes firms and organisations that provide specialist advice and coaching on regulation, clinical trial management, and technology and business management services. The CGTC is a key provider of regulatory advisory services, technology, funding, and is also an innovation broker in the RM innovation ecosystem and so falls within this business model. As discussed earlier RM SMEs do not possess in-house capabilities for all their operations and they depend on inter-firm linkages with translational service providers in the RM value chain to acquire products and services critical for progressing therapies down the translational pathway. 
The basis of this model is consultancy services and firms with expertise in certain aspects of the RM value chain, the first movers in the sector, have generated revenues by consulting for latecomer firms. A cell manufacturing case we studied termed this business model "contract translation" because they contracted out on regulatory, clinical development and contract manufacturing for other players leveraging their first mover advantage in these capabilities (CEO, Cell Manufacturing Case, 2015). However, due to high investment in infrastructure, technology and skills, and maintenance, publicly funded organisations tended to dominate this group. They worked closely with academics and SMEs from pre-clinical work to clinical trials, assisting with early development work, organ collection (for tissue-based therapies), cell manufacture and clinical trials. Publicly funded bodies are clear on their remit as reflected in this quote:

"We are a public sector organisation, we're not here to make money, we are here to do two things ...one is principally to provide a service for patients ... and to facilitate development of new cell therapies which might be service based like autologous therapies. ... [we are] not in competition with private companies, we're not trying to be. What we do is facilitate development of the private sector in this space..." (Director with a National Blood Transfusion Service body, 2015).

Market failure explains the dominance of public sector organisations because of lack of market led long-term investment for radical innovation with an uncertain future and no clear route to market. The government recognised that the high cost of investment in cGMP facilities was a translational impediment for RM therapy development and allocated $£ 55$ million over four years to the Cell and Gene Therapy Catapult to build a cGMP facility in Stevenage. In 2014, an additional $£ 12$ million was made available through UK Government, and a further $£ 30$ million was allocated in 2017 for investment in three new hospital based sites for new Advanced Therapy Treatment Centres. Our study however shows that this public investment in innovation infrastructure had unintended consequences on a cell manufacturing case that we studied. They argued that they could not compete with a more resourced CGTC, which raises an important issue of balancing public investment in innovation infrastructure and ensuring that public funded institutions do not crowd out innovative SMEs in the same space, as discussed in section 4.3.

\subsection{Virtual business model}

The Virtual Business Model applies to pre-revenue SMEs and university spinouts, which strategically defer investment in people, technology and infrastructure at early therapy development stages to reduce core-funding requirements. They do this to stretch research and development funding and move therapy development as far down the translational pathway as possible. One case currently using the Virtual Business Model described it as:

"So the [virtual] business model is that we pay for the expertise, we use....so we have no full time employees ... In terms of laboratories the research needed to bring the product forward was undertaken in my lab using funding initially from the [philanthropic funder] and then from [public funders] ... We also have some in-vivo work, some preclinical work done in London... So we don't own any labs, we don't rent any labs we simply pay for services whether its 
regulatory or laboratory or research or technical or advisory, that's what we mean by a virtual company. .... But the main driver was to keep costs down ... the last thing I wanted ... was to grow the company too quickly and have to close down because it was too expensive just to keep the company going" (CEO, early stage Cell Therapy case, 2015)

For business model theory, this is an interesting finding for emerging life sciences sectors, where financial strategy drives the architecture and structure of an enterprise to be dependent on established early stage RM value chain networks and linkages. This strategy is feasible for situations where, according to Gereffi et al (2005), technology can be codified and tacit knowledge is not dominant. The case quoted above was possible because the cell therapy firm can use codified standard processes in cell manufacture and the surgical process involving injecting cells into tissue. Our analysis suggests that the Virtual Business Model may be transitory as its key driver is scarce financial resources for early therapy development phases. We would argue that once some products are on the market firms would want to control as much of the value chain as they can. Enterprises using the Virtual Business Model depend entirely on linkages with their suppliers and as such, the coordination costs would be too high given the need to manage scheduling and logistics. Our study shows firms are using this model to access manufacturing scale up, quality assurance, regulatory and clinical trial advisory services.

\subsection{Fully integrated business model}

The fully integrated business model at this stage is a theoretical construct incorporating the previous five models, where the firm or organisation would control activities from the laboratory to the patient. This implies that the firm or organisation is able to bring in-house predominantly tacit knowledge capabilities characteristic of these innovative technologies, in line with Gereffi et al's (2005) hierarchy of value chain governance, given that RM products are complex, their specifications are largely not yet codified, knowledge is tacit, and there are no capable suppliers. All the 10 cases we studied had neither the financial resources nor inhouse capabilities to use this business model.

In this model, the firm develops RM therapies, manages IP, engages in managing clinical trials and related manufacturing scale up, acquires market authorisation and gets clinical adoption. A cell therapy case that had raised substantial amounts of funding on the equity market described their intended business model as:

"... we are a stem cell development business... [we] develop stem cell science, and ... translate them into commercial therapies. ... the business model ... is to take a number of selected stem cell based therapeutic candidates through pre-clinical and clinical development, ... to realise the commercial potential of those therapies" (Finance Director Cell Therapy Development Case, 2015).

This pre-revenue cell therapy development case's strategy was based on the end-point of having a Fully Integrated Business Model. However pragmatically they behaved to some extent as a hybrid Virtual Business Model and contracted out development, clinical trial work and manufacturing. They were classed as a hybrid Virtual Business Model because, even though they contracted out some services, they had core staff who did the bulk of the development work. During the financial downturn of 2008, they had to lay off staff to reduce 
their cash burn rate, because they were still a pre-revenue firm. In future, they plan to bring in-house most activities when their cGMP RM facility is completed. When they contractedout services, they retained and protected their intellectual property and trade secrets through contractual agreements. This case shows that there will be various forms of the Integrated Business Model as some activities are brought in-house, or where it is cheaper contractedout.

\section{Conclusion}

We argued that ex-poste application of traditional business model approaches are limited in their usefulness for RM. However, we acknowledged that the business model notion could be a useful heuristic tool for sense making in designing context-specific policy and practice, as well as investment interventions. We identified, characterised and analysed six interlinked business models whose evolving value chains still have gaps especially in healthcare settings. All six-business models are all still pre-revenue, except for manufacturing and scale-up, and as a result, all the business models are in a state of flux. This presents scalability and sustainability challenges for the sector.

As RM business models evolve, crowding-out tensions between the public and private sector may occur, and will need to be resolved timeously. Investment in manufacturing will be critical for the sector. Early integration into big pharma may be a hard sell because of differences in skills sets and business models. What may emerge initially could be "orphan drug" type sectors operating in parallel with the hospital exemptions. Designing policy and regulation that incentivises early stabilisation of the sector may promote faster development of the RM innovation ecosystem. This can build on current government investments that are bridging value chain gaps through innovation infrastructure and innovation brokers such as CGTC, clinical adoption centres, doctoral training centres, and RM Manufacturing centres of excellence. The public sector is best placed to invest in de-risking RM technology development and adoption early stages, and serves as a key signal to other traditional investors. Preemptive policy design that supports value chain upgrading paying particular attention to short, medium and long-term sustainability of the RM innovation eco-system, especially evolution of a broad base of SMEs that can take over when public funding is withdrawn will be complex. A proportionate and adaptive regulatory environment would be critical to supporting evolving business models even as value chain upgrading occurs.

\section{References}

Afuah, A., and Tucci, C., (2003). Internet Business Models and Strategies. Boston, McGraw Hill.

Al-Debei, M. M., \& Avison, D. (2010). Developing a unified framework of the business model concept. European Journal of Information Systems, 19(3), 359-376.

Amit, R., and Zott, C., (2001) "Value creation in e-business." Strategic Management Journal 22:493-520. 
Banda, G., Tait, J., and Mittra, J., (2018) Evolution of Business Models in Regenerative Medicine: Effects of a Disruptive Innovation on the Innovation Ecosystem. Clinical Therapeutics 40 (7).

BIS (2011) Taking Stock of Regenerative Medicine in the United Kingdom. Office for Life Sciences. Department for Business, Innovation \& Skills.

https://assets.publishing.service.gov.uk/government/uploads/system/uploads/attachment_ data/file/32459/11-1056-taking-stock-of-regenerative-medicine.pdf

BIS (2013). The 'eight great technologies' which will propel the UK to future growth receive a funding boost. Department for Business, Innovation \& Skills. https://www.gov.uk/government/speeches/eight-great-technologies

Chesbrough, H. \& Rosenbloom, R. S. 2002. The role of the business model in capturing value from innovation: evidence from Xerox Corporation's technology spin-off companies. Industrial \& Corporate Change, 11, 529-555.

Couto, D. S., Perez-Breva, L, and Cooney, C.L., (2012). "Regenerative Medicine: Learning from Past Examples." Tissue Engineering Part A (2012): 120725085622009. Mary Ann Liebert, Inc. publishers. http://dx.doi.org/10.1089/ten.TEA.2011.0639

Franklin, S., and Kaftantzi, L., (2008). Industry in the Middle: Interview with Intercytex Founder and CSO, Dr Paul Kemp. Science as Culture. 17 (4), 449-462. DOI: 10. 1080/0950543080251520

Gereffi, G., Humphrey, J., Sturgeon, T. (2005). The governance of global value chains. Review of International Political Economy, 12 (1) 78-104.

Gordijn, J. (2002). Value-based Requirements Engineering - Exploring Innovative eCommerce Ideas. Amsterdam, NL, Vrije Universiteit.

HOL S\&TC (2013) Regenerative Medicine Report, HL Paper 23. London: HMSO, 1 July 2013. Jensen, A.B., (2013). Do we need one business model definition? Journal of Business Models. 1(1): 61-84.

Linder, J., and Cantrell, S., (2000) So what is a business model anyway. Accenture Institute for High Performance Business.

Mittra, J., Maestroeni, M., Turner, M.L., Mountford, J.C., and Bruce, K., (2014). Identifying viable regulatory and innovation pathways for regenerative medicine: a case study of cultured red blood cells. New Biotechnology. 0 (0): 1-11.

Mittra, J., (2016). The New Health Bioeconomy: R\&D Policy and Innovation for the TwentyFirst Century. Palgrave Macmillan, NY, USA.

Mittra, J., and Tait, J., (2012). "Analysing Stratified Medicine Business Models and Value Systems: Innovation-Regulation Interactions". New Biotechnology, 29(6): 709-719. 
Omidvar, O., De Grijs, M., Castle, D., Mittra, J., Rosiello, A., and Tait, J., (2014). Regenerative Medicine: Business Models, Venture capital and Funding Gap. Innogen Report. The Innogen Institute. Edinburgh. UK

Osterwalder, A., Pigneur, Y., and Tucci, C.L., (2005). Clarifying Business Models: Origins, Present and Future of the Concept. Communications of the Association for Information Systems. 16: 1-25

Perkmann. M., Spicer, A., (2010), What are business models? Developing a theory of performative representations, in Nelson Phillips, Graham Sewell, Dorothy Griffiths (ed.) Technology and Organization: Essays in Honour of Joan Woodward (Research in the Sociology of Organizations, Volume 29) Emerald Group Publishing Limited, pp.265 - 275

Petrovic, O., Kittl, C., and Teksten, R.D., (2001) Developing business models for ebusiness, International Electronic Commerce Conference, Vienna.

Pisano, G. P., (2006) Science Business: The Promise, the Reality, and the Future of Biotech. Harvard Business School Press.

Porter, M.E., 1985. Competitive advantage: creating and sustaining superior performance. 1985.

Santos, J., Spector, B., and Van Der Heyden, L., (2009). Towards a Theory of Business Model Innovation within Incumbent Firms. Insead Working Paper Series. Fontainebleau Cedex, France.

Tait, J., and Banda, G., (2016). Proportionate and adaptive governance of innovative technologies Financial Technologies (FinTech), Cell Therapies and Synthetic Biology: The role of regulations, guidelines and standards. BSI (British Standards Institution).

https://www.bsigroup.com/LocalFiles/en-

GB/BIS/Innovate\%20UK\%20and\%20emerging\%20technologies/Summary\%20Report\%20\%20Adaptive\%20governance\%20-\%20WEB.pdf

Tait, J., Banda, G., and Watkins, A., (2017). Proportionate and Adaptive Governance of Innovative Technologies (PAGIT): A Framework to Guide Policy and Regulatory Decision Making. BSI (British Standards Institution). https://www.innogen.ac.uk/downloads/FrameworkReport-Final 170717.pdf

Teece, D., (2010). Business Models, Business Strategy and Innovation. Long Range Planning. 43: $172-194$

Trimmers, P., (1998) “Business models for electronic markets." Electronic Markets 8(2):3-8.

Wang, T., (2013). A Survey of Current Landscape in Regenerative Medicine- Fast Evolving Field Albeit Accompanied by High Risk. Mizuho Industry Focus Vol 141.

Weill, P., and Vitale, M., (2002). "What IT infrastructure capabilities are needed to implement ebusiness models?" Mis Quarterly 1(1): 17-34. 
Yin, K. Y., 2003. Case Study Research Design and Methods. London, Sage Publications.

Zott, C. and Amit, R., 2008. The fit between product market strategy and business model: implications for firm performance. Strategic management journal, 29(1), pp.1-26. 